France); Professor Taylor Cole (Duke University); Professor T. Cavalcanti, president of the Brazilian Institute of Public Iaw and Political Science; and M. Jean Meynaud, secretary-general of IPSA. Professor M. Ginsberg (The London School of Economics and Political Science) was elected chairman, and M. Meynaud rapporteur.

For part of the sessions, discussion was carried on in three sub-committees: one on the status of the social sciences in universities (Professor Duverger, chairman); one on the role of the social sciences in general education and as a preparation for particular professions (Professor Robson, chairman); and one on the training and recruitment of professors and methods of teaching (Professor J. N. Hazard, Columbia University, chairman). Plenary sessions discussed the reports submitted by each of the sub-committees and reached a certain number of conclusions aiming at the development and improvement of social science teaching.

UNESCO is to publish in 1953 a volume containing the overall reports set up under the responsibility of the International Associations (especially Professor Robson's report). Pamphlets on the teaching of social sciences within three of the surveyed countries (United States, France, and Great Britain) will also be published. The material gathered during this inquiry and the conclusions reached will be valuable, particularly for countries in which social science teaching has not yet been developed extensively.-J. MEYNAUD.

\title{
ANNUAL MEETING OF AMERICAN COUNCIL OF LEARNED SOCIETIES
}

The thirty-sixth annual meeting of the American Council of Learned Societies met at Rye, New York, on January 20-23, 1953. All of the twenty-four constituent societies were represented by delegates, one from each society. Prior to this meeting, the annual conference of secretaries of the constituent societies was held; the secretaries also attended the sessions of the Council. Edward H. Litchfield represented the American Political Science Association as executive director and Kenneth Colegrove as delegate. Unlike usual annual meetings of the ACLS, no representatives of the foundations were present.

Cornelius Krusé, professor of philosophy of Wesleyan University, retired as chairman of the ACLS after service of five years in this post. President C. W. de Kiewiet, of the University of Rochester, was elected as his successor. On September 1, 1952, Dr. Charles E. Odegaard, the executive-director, resigned. A veteran staff member, Mortimer Graves, has served as acting executive-director. The Board of Directors is now engaged in selecting a permanent executive-director.

During 1952, the Council received from various sources a total of $\$ 981,421.26$. Of this amount, it disbursed $\$ 644,581.87$. The treasurer's report will be published in the Bulletin: American Council of Learned Societies for March, 1953. A summary of the wide activities of the ACLS for the year 1952 follows in somewhat abbreviated form.

Standing Enterprises and Operations. Of the standing enterprises of the ACLS, no progress can be reported on the Linguistic Atlas of the United States and Canada, although the search for funds for its continustion has been maintained. As to the Dictionary of American Biography, there is hope that publication of the supplementary volumes may be resumed. The first supplementary volume, published in 1944, brought the Dictionary down to December 31, 1935.

The Council's long continued interest in the study of Asia resulted in the production in the middle of 1951 of $A$ Program for the Improvement of American Undersianding of Asian Civilizations, comprising eight memoranda covering eight points in such a program. This was presented to the Ford Foundation, which organized its own program of fellowships in the amount of $\$ 500,000$ in 1952 ; it has just announced a similar program for the current year. For basic implementation of the study of Asian languages, including elementary texts, graded readings, and students' dictionaries, the Ford Foundation has made available to the ACLS the sum of $\$ 250,000$ over a three-year period beginning in 1952. The operation is now under way. Discussion with the Ford Foundation respecting the later elements of the eightpoint program is proceeding, and there is every expectation that some of these will be actualized in the future.

The ACLS Committee on the Language Program continues the work begun under the various ACLS-U. S. Army language programs 
during World War II. Its most significant operations are: (1) a program producing for the U. S. Department of State elementary textbooks for teaching English to speakers of eleven Asian and East European languages; (2) the new program in Asian language materials for Americans mentioned above; and (3) summer-study aids in linguistics.

The Committee on American Civilization was responsible for the organization of a series of Conferences on "Changes in Systems of Belief in the United States since World War I." The Committee on the History of Religions sponsored Profestor Louis Massignon, of the Collège de France, in a series of lectures on Islamic Mysticism. It continued its editing of readers in the world's religious literatures. The first of these, Buddhism: A Religion of Infinite Compassion, was published early in 1952. The Committee on the Humanistic Aspects of Science carried on its work of preparing an annotated bibliography. The Committie on Musicology evaluated its Conference on Music in American Life.

The ACLS, in cooperation with the Ameriean Council on Education, the National Research Council, and the Social Science Research Council, continued to be represented on the Committee on International Exchange of Persons, the principal function of which is to advise concerning the selection of professors, lecturers, and research scholars for appointments under the Fulbright program. The Joint Committee on the Recovery of Archaeological Remains extended its activities beyond the borders of the United States by advising the Technical Co-operation Administration on establishing archaeological salvage programs in foreign countries under the Point Four Program. The two regional interests of the ACLS, the Southern Humanities Conference and the Pacific Coast Committee for the Humanities, continue to be restricted by lack of funds.

Fellowships. During 1952, the following awards were administered by the ACLS: 15 first-year graduate fellowships, 25 advanced graduate fellowships, 18 faculty study fellowships, 19 ACLS scholars' grants, and 45 summer study aids in linguistics. Lists of these awards have appeared in the ACLS Newsletter. The need to assist graduate students and faculty members in the fields of the humanities is much greater than the programs of aid available. Indeed, the ACLS, through lack of funds, will apparently not be able to operate any fellowship programs for 1953-1954, except the summer study aids in linguistics.
Personnel Studies Program. The ACLS Personnel Studies program has been largely occupied during the past year in completing the collection phase of the National Registration in the Humanities and the Social Sciences. Altogether, some 27,000 schedules were received from 55,800 individuals queried. Altogether, twenty-three different societies, sixteen of them constituents of the ACLS, cooperated in the program. Fifteen separate classification checklists were devised. There were some complaints about the program, the more general ones concerning themselves with the use of humanistic scholars in connection with militaristic programs. The staff adviser attempted a formalized answer to objections of this kind which was embodied in an article entitled "Cast Out the Beam Out of Thine Own Eye," published in the May issue of the ACLS Newsletter.

Plans for the analysis of registration materials are going forward. The U. S. Bureau of Labor Statistics expects to produce a general statement with as much detail on separate fields as their numbers and importance in the view of government agencies seem to warrant. Additional analyses will be arranged if necessary by the ACLS, and in some cases cooperating societies are actively concerned. In addition to the basic analytical program, registration materials are being used experimentally for purposes of locating scholars with specific combinations of skills and experience. It is hoped that such use can be regularized and made more widely available.

Beyond these activities, a staff adviser has worked with the National Scientific Register, the National Science Foundation, the National Research Council, the Defense Manpower Administration, the Committee on Relationships with the Federal Government of the American Council on Education, and the United States Employment Service of the U. S. Department of Labor.

Publications. The ACLS has continued to explore the means for cheaper methods of manufacture of books in the interest of scholarly publication. The publications of the ACLS during the last two years have been reflections of these experiments in manufacture, and nearly all of the volumes on the list of publications during 1952 have been prepared on an IBM typewriter in the rooms over the garage at the rear of the ACLS offices, and have been brought up to the lithoprinter's camera with a minimum of expense. While the principal purpose of the operation has been to secure de- 
pendable figures on costs, the enterprise has carried itself, including amortization of the initial capital outlay for equipment on an actuarial basis, besides providing composition at a low cost. A total of 7,247 pages has been prepared for the camera, of which 3,251 pages were produced in 1952. This service is available at a trifle over cost to the constituent societies.

It is becoming increasingly evident that the problem of scholarly publication is not limited solely to production. The question of distribution also looms large. During the coming month3, emphasis will be placed on ways of reaching the potential market for scholarly books. Here, as with production, the ACLS is in a position to experiment with its own pubcations. As a first step, a list of all ACLS publications was included in the summer issue of the Newsletter, and subsequent issues have included mention of new books as they have appeared. The formulation of specialized mailing lists and direct approaches to college and university libraries are but two of the ways being considered to bring these publications to the attention of a wider public.

Area Studies. ACLS activities in the field which has come to be known, though unsatisfactorily, as "area studies" have been continuous over the past couple of decades and occupied a considerable part in the operations of 1952.

The Committee on Far Eastern Studies met once in Boston, on the occasion of the annual meetings of the American Oriental Society and the Far Eastern Association. Publication of $A$ List of Published Translations from Chinese into English, French, and German (Part I, Literature exclusive of Poetry) was finally consummated. The Committee on Near Eastern Studies met twice, both times in New York. Progress was reported on enterprises already under way, such as the Near Eastern Translation Program and Books and Periodicals in Western Languages Dealing with the Near and Middle East. Elwell-Sutton's Guide to Iranian Area Study came from the press.

The Committee on Slavic Studies met once in New York. The Russian Translation Program and the Current Digest of the Soviet Press proceeded throughout the year. The former, with twenty-one volumes published or in press, comes to an end with the year as a result of the termination of the subvention. The Current Digest, now in its fourth year, seems assured, through action of the Rockefeller Foundation and the East European
Fund, until 1958. The Committee sponsored a Conference on Soviet Economic Growth in New York on May 23-25, and is planning a similar Conference on Russian Intellectual History.

The Committee on South Asian Studies met once in New York. Under joint sponsorship with the Library of Congress, a quarterly accessions list, Southern Asia: Publications in Western Languages, appeared.

In the field of Canadian studies, members of the executive staff joined with representatives of the University of Rochester and invited specialists to discuss the question of intellectual relations between the United States and Canada.

For the decade prior to 1948, the ACLS maintained, either by itself or jointly with other Councils, a Committee on Latin American Studies. Recently, the question has been raised as to the advisability of reconstituting an ACLS committee in this field. On May 12, advantage was taken of another meeting of Latin American specialists in New Orleans to hold a conference of specialist s from southern institutions. The conference produced an interesting discussion but no very significant proposals as to future operations.

Mortimer Graves suggests that current experience with committees on areas raises a question as to whether we are not beginning to reach a point of diminishing returns from this form of organizational procedure. It is true that for twenty years some of the Council's most spectacular and effective work has been that connected with the committees on underworked area fields. It is equally true that we must question whether continued emplasis on the need for more fellowships, publication opportunities, funds for individual and collective enterprises of research, tools of study, and the acquisition and rendering available of research materials serves a very useful purpose. It is not that these needs are nonexistent; it is that they are not peculiar to the underworked fields of scholarship, but are common to all fields of the humanities.

Other attacks on the same problem should be explored. The most active committee of the ACLS, the Committee on the Language Program, concerns itself with all language and linguistic problems, no matter what the area of their reference. A proposal has recently been made that the ACLS assume an operation of some sort in the field of Oriental philosophy, designed to insinuate concern with Oriental philosophies into philosophy departments. 
This is not to argue that we should forsake the areal for the disciplinary or departmental basis in the creation of ACLS committees, but only to point out that there is here an organizational problem which should engage our attention.

Miscellaneous. This year, the executive staff made progress in improving communication between the Council and its widening clientele. The Newsletter, started some three and a half years ago in an attempt to bring ACLS activities to the attention of a scholarly public beyond those individuals who were intimately associated with the Council or with its committees, is now being published on a quarterly basis. Individuals on fifty campuses have agreed to act as unofficial representatives of the Council and have accepted responsibility for publicizing $\Lambda$ CLS activities among their colleagues.

Three members of the staff represent the ACLS on the twelve-member Committee of the Conference Board of Associated Research Councils. Its primary function-the selection of lecturers and advanced research workers for assistance under the Fulbright operation-has been expanded not only by the increasing number of countries being brought into the Fulbright program but also by the introduction into the operation of a much higher degree of planning, especially in the nature of special recruitment, and by the addition of responsibilities in the administration of dollar funds from the Whitney and Ford Foundations for foreign scholars eligible to Fulbright travel grants. The current work load on members is consequently very great and only to be justified if the program is of commensurate value to American scholarship.

The Humanities in the Next Decade. The greater part of the time of the Council at the 1953 annual meeting was devoted to the discussion of the humanities in the next decade. Discussion proceeded on the basis of a carefully drafted paper by Mortimer Graves and other members of the staff. In 1951, the Carnegie Corporation made the ACLS a terminal grant for general support, while the Rockefeller Foundation sharply reduced its support for administration, planning and fellowships. The Rockefeller Foundation explained its action as stemming not from any dissatisfaction witb the achievements of the Council but rather from a belief that "as the representative of humanistic scholarship in the United States, the Council should not be dependent on any single agency for so large a proportion of its support." In 1952, the Ford Foundation made a grant of $\$ 250,000$ to the ACLS over a threeyear period for the study of Asian languages. This is a promising start with the new and mammoth educational foundation, but it does not fully answer the problem of future support of the Council.

Delegates from the constituent societies agreed that there is an unfortunate tendency to take the humanities for granted. At the same time, even among the constituent societies, there is wide ignorance regarding the activities of the ACLS. As a holding company for the humanities, there is need for better public relations. In the words of Frank Knight, scholarship is a hard product to sell in a democratic society for the reason that the truth seldom sells itself. In spite of the lip service paid to the humanities, there is incessant need for defending the very existence of the study of mankind.

In the field of personnel, the humanities have consistently lost ground to the physical sciences, and even to the social sciences within their own circle. By 1965, the college population will probably be 85 per cent greater than today, unless some other educational process besides the college be devised. There are now approximately 50,000 permanently employed teachers of the humanities and social sciences in American colleges and universities. On the assumption that an increase of students calls for a commensurate increase of teachers, we shall need as many as 40,000 new teachers in 1965 , to say nothing of replacements, half of whom should be in the humanities. But at the slow rate that scholars are being drawn into the professional humanities we will not be able to meet the increased demand for teachers without a destructive lowering of standards. Obviously, this problem requires a study of the life-cycle of the humanistic scholar as well as the development of fellowships and other means of promoting research.

Some delegates detected a breach between the humaniats and the social scientists; others thought that there was no more than an unhappy lack of cooperation. Even if the latter is true, such lack of cooperation indicates an absence of realism on both sides. If the humanities be the study of man and of man's belief in mankind, then it is difficuit to see how either discipline can forego the closest contact with the other. Some humanists claimed that the tax-exempt foundations had lost confidence in the social scientists and that humanists would do well to cash in on this opportunity 
by giving more attention to current problems. The accuracy of the allegation was disputed, and again cooperation was advised. It was generally agreed that there is no harmful competition between the ACLS and the Social Science Research Council. As planning and promoting agencies for scholarship, both organizations possess the highest utilitarian value.

Most delegates were of the opinion that scholars should bring the humanities to the general public by more effective writing for public consumption. Even among the humanities, which includes literature, the ability to combine scholarship with popular writing is all too rare. There should be no aspersions cast upon scholars who write popular books without loss of their intellectual honesty. If the scholarship is sound, the fact that such publication is financially profitable does not impair its intrinsic value nor it usefulness to the human race.

There was general agreement that the ACLS requires an endowment for administration and planning. To find more than the two or three million dollars necessary for an administrative endowment would be an impossible task. But even in attempting to raise this endowment, the ACLS should not proceed in any way to lessen the responsibility of the foundations for support of the planning and operation of scholarly activities by the Council.-KENneth Colegrove.

\section{OTHER ACTIVITIES}

Formation of a study group to reappraise the foreign economic policy of the United States was jointly announced in November by the Woodrow Wilson Foundation and the National Planning Association. The eight members of the group are: William Y. Elliott, Assistant to the Director for Foreign Activities, Office of Defense Mobilization, and Williams Professor of Government at Harvard University, chairman; Richard M. Bissell, Jr., consultant, Ford Foundation, and formerly Deputy Administrator of ECA; Courtney C. Brown, Assistant to the Chairman of the Board, Standard Oil Company of New Jersey; H. van B. Cleveland, Committee for Economic Development; Theodore Geiger, Chief of Research, National Planning Association; Harry D. Gideonse, President, Brooklyn College; Edward 8. Mason, Dean, Littauer School of Public Administration, Harvard University; and Don K. Price, Deputy Chairman, Research and Development Board, Office of the Secretary of Defense.

The study group will examine the basic assumptions about the nature of the world economy on which the United States policy has been based and the specific methods by which we have been attempting to make our policy effective during the postwar period. In their final report, the members will assess the degree of success which our foreign economic policy has had to date, will analyze the main reasons why our policy has not been more successful, and will suggest the modifications, both in concept and in methods, which their findings show to be desirable. The group has agreed on an outline of its work and will ultimately prepare a book-length report of its findings and conclusions.

The National Planning Association has set up a Special Policy Committee on the Organization of the Executive Office of the President to recommend means of improving the President's staff. The Committee includes nineteen members who have long and varied experience with top-management problems gained in business, government, and the study of public administration. Sumner T. Pike, for six years a member of the Atomic Energy Commission and a former member of the Securities and Exchange Commission, has been designated chairman. Political scientist members of the NPA Committee include Louis Brownlow, Luther H. Gulick, and John D. Millett.

A constitutional convention of 99 members will meet at Nashville, Tennessee, in April, 1953 , to undertake a limited revision of the state constitution. The convention is authorized to consider the amending clause, the compensation and expenses of legislators, the veto power, the right of suffrage, home rule, and local governmental consolidation. Professor Frank Prescott, of the University of Chattanooga, and Dr. C. C. Sims, of Middle Tennessee State College, are among the delegates. A voluntary group of political scientists and law teachers has been organized to provide studies for the delegates.

Boston University has announced the establishment of an African Research and Studies Program to be inaugurated formally on July 1, 1953. Dr. William O. Brown, now Chief of the African Research Branch in the U. S. Depart- 